\title{
The polio vaccine: a critical assessment of its arcane history, efficacy, and long-term health-related consequences
}

\author{
Neil Z. Miller \\ Thinktwice Global Vaccine Institute \\ P.O. Box 9638 \\ Santa Fe, NM 87504 USA \\ Website: www.thinktwice.com
}

\begin{abstract}
Polio (poliomyelitis) is a potentially dangerous viral ailment. To combat this disease, researchers developed two polio vaccines (inactivated and live) grown in cultures made from monkey kidneys. Beginning in the 1950s, these vaccines were administered to millions of people in the United States and throughout the world. Officially, the polio vaccine is considered safe and effective, and has been credited with singularly reducing the incidence of this disease. These tenets are not supported by the data.

A cancer-causing monkey virus-SV-40-was discovered in polio vaccines administered to millions of people. SV-40 has been found in brain tumors, bone cancers, lung cancers and leukemia. SV-40 is transmitted through sexual intercourse, and from mother to child in the womb. Monkeys that were used to make polio vaccines were infected with simian immunodeficiency virus (SIV), a virus closely related to human immunodeficiency virus (HIV), the infectious agent associated with AIDS. Some researchers question whether HIVs may simply be SIVs "residing in and adapting to a human host." Polio vaccines also contain calf serum, glycerol and other parts of the cow that may have been infected with bovine spongiform encephalopathy (BSE), or mad cow disease, a fatal brain-wasting ailment that some researchers link to Cruetzfeldt-Jakob disease (CJD), its human equivalent.

Current disease reduction techniques that emphasize short-term gains over long-term health consequences need to be reevaluated and discontinued while new and safer health paradigms are researched and implemented.

CCopyright 2004, Neil Z. Miller. All rights reserved.
\end{abstract}

Keywords: polio, aseptic meningitis, simian virus, SV-40, bovine spongiform encephalopathy, BSE, vCJD

\section{What is polio?}

Polio is a contagious disease caused by an intestinal virus that may attack nerve cells of the brain and spinal cord. Symptoms include fever, headache, sore throat, and vomiting. Some victims develop neurological complications, including stiffness of the neck and back, weak muscles, pain in the joints, and paralysis of one or more limbs or respiratory muscles. In severe cases it may be fatal, due to respiratory paralysis.

\section{How is polio contracted?}

Polio can be spread through contact with contaminated feces (for example, by changing an infected baby's diapers) or through airborne droplets, in food, or in water. The virus enters the body by nose or mouth, then travels to the intestines where it incubates. Next, it enters the bloodstream where "anti-polio" antibodies are produced. In most cases, this stops the progression of the virus and the individual gains permanent immunity against the disease [1].

Many people mistakenly believe that anyone who contracts polio will become paralyzed or die. However, in most infections caused by polio there are few distinctive symptoms [2]. In fact, 95 percent of everyone who is exposed to the natural polio virus won't exhibit any symptoms, even under epidemic conditions $[3,4]$. About 5 percent of infected people will experience mild symptoms, such as a sore throat, stiff neck, headache, and feveroften diagnosed as a cold or flu [3,5]. Muscular paralysis has been estimated to occur in about one of every 1,000 people who contract the disease $[3,6]$. This has lead some scientific researchers to conclude that the small percentage of people who do develop paralytic polio may be anatomically susceptible to the disease. The vast remainder of the population may be naturally immune to the polio virus [7].
Injections: Several studies have shown that injections (for antibiotics or other vaccines) increase susceptibility to polio. In fact, researchers have known since the early 1900s that paralytic poliomyelitis often started at the site of an injection [8,9]. When diphtheria and pertussis vaccines were introduced in the 1940s, cases of paralytic poliomyelitis skyrocketed (Figure 1) [10]. This was documented in Lancet and other medical journals [11-13]. In 1949, the Medical Research Council in Great Britain set up a committee to investigate the matter and ultimately concluded that individuals are at increased risk of paralysis for 30 days following injections; injections alter the distribution of paralysis; and it did not matter whether the injections were subcutaneous or intramuscular $[14,15]$.

Figure 1. Polio cases skyrocketed after diphtheria and pertussis vaccines were introduced

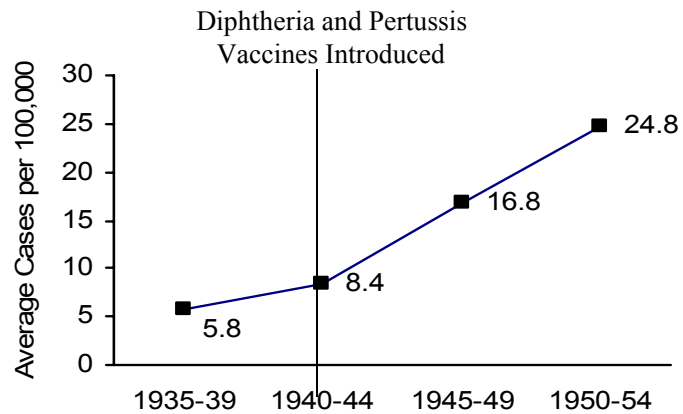

Several studies show that injections increase susceptibility to polio. When diphtheria and pertussis vaccines were introduced in the 1940 s, cases of paralytic poliomyelitis skyrocketed. This chart shows the average number of polio cases per 100,000 people during five year periods before and after the vaccines were introduced. Source: National Morbidity Reports taken from U.S. Public Health surveillance reports; Lancet (April 18, 1950), pp. 659-63. 
A 1992 study, published in the Journal of Infectious Diseases, validated earlier findings. Children who received DPT (diphtheria, tetanus, and pertussis) injections were significantly more likely than controls to suffer paralytic poliomyelitis within the next 30 days [16]. According to the authors, "this study confirms that injections are an important cause of provocative poliomyelitis [16:444]."

In 1995, the New England Journal of Medicine published a study showing that children who received a single injection within one month after receiving a polio vaccine were 8 times more likely to contract polio than children who received no injections. The risk jumped 27-fold when children received up to nine injections within one month after receiving the polio vaccine. And with ten or more injections, the likelihood of developing polio was 182 times greater than expected [17].

Why injections increase the risk of polio is unclear [18]. Nevertheless, these studies and others [19-24] indicate that "injections must be avoided in countries with endemic poliomyelitis [18]." Health authorities believe that all "unnecessary" injections should be avoided as well [18:1006;24].

Nutritional deficiencies: A poor diet has also been shown to increase susceptibility to polio [25]. In 1948, during the height of the polio epidemics, Dr. Benjamin Sandler, a nutritional expert at the Oteen Veterans' Hospital, documented a relationship between polio and an excessive use of sugars and starches. He compiled records showing that countries with the highest per capita consumption of sugar, such as the United States, Britain, Australia, Canada, and Sweden (with over 100 pounds per person per year) had the greatest incidence of polio [26]. In contrast, polio was practically unheard of in China (with its sugar use of only 3 pounds per person per year) [26].

Dr. Sandler claimed that sugars and starches lower blood sugar levels causing hypoglycemia, and that phosphoric acid in soft drinks strips the nerves of proper nourishment. Such foods dehydrate the cells and leech calcium from the body. A serious calcium deficiency precedes polio [26-29]. Weakened nerve trunks are then more likely to malfunction and the victim loses the use of one or more limbs [26:146].

Researchers have always known that polio strikes with its greatest intensity during the hot summer months. Dr. Sandler observed that children consume greater amounts of ice cream, soft drinks, and artificially sweetened products in hot weather. In 1949, before the polio season began, he warned the residents of North Carolina, through the newspapers and radio, to decrease their consumption of these products. That summer, North Carolinians reduced their intake of sugar by 90 percent-and polio decreased by the same amount! The North Carolina State Health Department reported 2,498 cases of polio in 1948, and 229 cases in 1949 (data taken from North Carolina State Health Department figures) [26:146;29].

One manufacturer shipped one million less gallons of ice cream during the first week alone following the publication of Dr. Sandler's anti-polio diet. Soft drink sales were down as well. But the powerful Rockefeller Milk Trust, which sold frozen products to North Carolinians, combined forces with soft drink business leaders and convinced the people that Sandler's findings were a myth and the polio figures a fluke. By the summer of 1950 sales were back to previous levels and polio cases returned to "normal" [26:146;29].

\section{Can polio be treated?}

Paralytic polio is rarely permanent. Usually there is a full recovery [30-34]. Muscle power begins to return after several days and continues to improve during the next 12-24 months [30-34]. A small percentage of cases will experience residual paralysis. In rare cases, paralysis of the muscles used to breathe can lead to death [5:108;30-34].

Treatment mainly consists of putting the patient to bed and allowing the affected limbs to be completely relaxed. If breathing is affected, a respirator or iron lung can be used. Physical therapy may be required.

\section{Does a polio vaccine exist?}

In 1947, Jonas Salk, an American physician and microbiologist, became head of the Virus Research Laboratory at the University of Pittsburgh. He was interested in developing a polio vaccine. In 1952, Salk combined three types of polio virus grown in cultures made from monkey kidneys. Using formaldehyde, he was able to "kill" or inactivate the viral matter so that it would trigger an antibody response without causing the disease. That year he began his initial experiments on human subjects. In 1953, his findings were published in the Journal of the American Medical Association. And in April of 1954 the nation's first polio immunization campaign, directed at school children, was launched [35]. However, shortly thereafter hundreds of people contracted polio from Salk's vaccine; many died. Apparently, his "killed-virus" vaccine was not completely inactivated [1]. The vaccine was redeveloped, and by August 1955 over 4 million doses were administered in the United States. By 1959, nearly 100 other countries were using Salk's vaccine $[1,35]$.

In 1957, Albert Sabin, another American physician and microbiologist, developed a live-virus (oral) vaccine against polio. He didn't think Salk's killed-virus vaccine would be effective in preventing epidemics. He wanted his vaccine to simulate a real-life infection. This meant using an attenuated or weakened form of the live virus. He experimented with thousands of monkeys and chimpanzees before isolating a rare type of polio virus that would reproduce in the intestinal tract without penetrating the central nervous system. The initial human trials were conducted in foreign countries. In 1958, it was tested in the United States. And in 1963 Sabin's oral "sugar-cube" vaccine became available for general use $[1,35]$.

\section{Which vaccine is in use today?}

In 1963, Sabin's oral vaccine quickly replaced Salk's injectable shot. It is cheaper to make, easier to take, and appears to provide greater protection, including "herd immunity" in unvaccinated people. However, it cannot be given to people with compromised immune systems $[1,35]$. Plus, it is capable of causing polio in some recipients of the vaccine, and in individuals with compromised immune systems who come into close contact with recently vaccinated children [1,35-38]. As a result, in January 2000, the CDC "updated" its polio vaccine recommendations, reverting back to policies first implemented during the 1950s: Children should 
only be given the killed-virus shot. The oral polio vaccine should only be used in "special circumstances [39-41]."

\section{Are polio vaccines safe?}

When national immunization campaigns were initiated in the 1950s, the number of reported cases of polio following mass inoculations with the killed-virus vaccine was significantly greater than before mass inoculations, and may have more than doubled in the U.S. as a whole. For example, Vermont reported 15 cases of polio during the one-year report period ending August 30, 1954 (before mass inoculations), compared to 55 cases of polio during the one-year period ending August 30, 1955 (after mass inoculations)-a 266\% increase. Rhode Island reported 22 cases during the before inoculations period as compared to 122 cases during the after inoculations period-a 454\% increase. In New Hampshire the figures increased from 38 to 129; in Connecticut they rose from 144 to 276; and in Massachusetts they swelled from 273 to 2027-a whopping 642\% increase (Figure 2) [26:140;29:146;42].

Figure 2. Cases of polio increased in the U.S. after mass inoculations

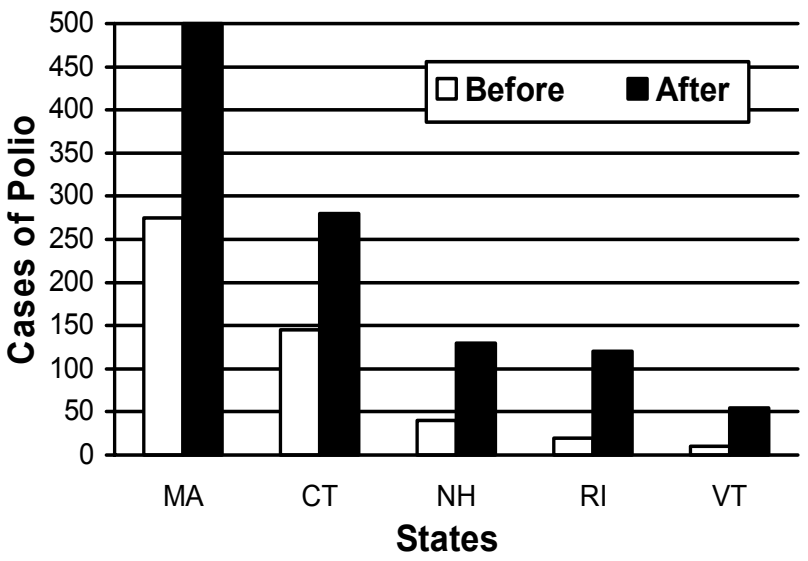

When national immunization campaigns were initiated in the $1950 \mathrm{~s}$, the number of reported cases of polio following mass inoculations with the killed-virus vaccine was significantly greater than before mass inoculations, and may have more than doubled in the U.S. as a whole. Source: U.S. Government statistics.

Doctors and scientists on the staff of the National Institutes of Health during the 1950s were well aware that the Salk vaccine was causing polio. Some frankly stated that it was "worthless as a preventive and dangerous to take [26:142]." They refused to vaccinate their own children [26:142]. Health departments banned the inoculations [26:140]. The Idaho State Health Director angrily declared: "I hold the Salk vaccine and its manufacturers responsible" for a polio outbreak that killed several Idahoans and hospitalized dozens more [26:140]. Even Salk himself was quoted as saying: "When you inoculate children with a polio vaccine you don't sleep well for two or three weeks [26:144;43]." But the National Foundation for Infantile Paralysis, and drug companies with large investments in the vaccine coerced the U.S. Public Health Service into falsely proclaiming the vaccine was safe and effective [26:142-5].

In 1976, Dr. Jonas Salk, creator of the killed-virus vaccine used in the 1950s, testified that the live-virus vaccine (used almost ex- clusively in the U.S. from the early 1960s to 2000) was the "principal if not sole cause" of all reported polio cases in the U.S. since 1961 [44]. (The virus remains in the throat for one to two weeks and in the feces for up to two months. Thus, vaccine recipients are at risk, and can potentially spread the disease, as long as fecal excretion of the virus continues [45].) In 1992, the Federal Centers for Disease Control and Prevention (CDC) published an admission that the live-virus vaccine had become the dominant cause of polio in the United States [36]. In fact, according to CDC figures, every case of polio in the U.S. since 1979 was caused by the oral polio vaccine [36]. Authorities claim the vaccine was responsible for about eight cases of polio every year [46]. However, an independent study that analyzed the government's own vaccine database during a recent period of less than five years uncovered 13,641 reports of adverse events following use of the oral polio vaccine. These reports included 6,364 emergency room visits and 540 deaths (Figure 3) [47,48]. Public outrage at these tragedies became the impetus for removing the oral polio vaccine from immunization schedules [36:568;37;38].

Figure 3. Polio vaccine: adverse and serious adverse reactions

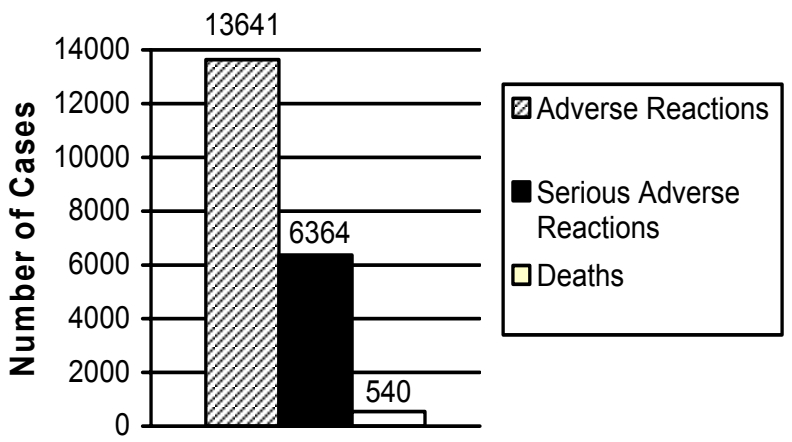

In the mid-1990s, during a period of less than five years, there were 13,641 documented adverse reactions to the oral polio vaccine. 6,364 of these were serious enough to require hospital emergency room visits. 540 people died. Source: Vaccine Adverse Event Reporting System (VAERS); OPV Vaccine Report: Doc. \#14.

The following story is typical of the damage associated with oral polio vaccines: "Four months ago my son was taken to a local clinic for his polio vaccine. I wasn't aware that he was going to have one, and would have prevented it if I had known. Unfortunately, he changed from that day-high-pitched screaming, smelly stools, non-stop crying, difficulty in breathing, high temperature, and lethargy. He also lost weight. Weeks of sleepless nights for all of us followed. His development ceased. He had been able to stand and move around, but he went back to remaining in basically whatever position we left him in.

"My wife was six months pregnant at the time, and about a week after our son's polio vaccine, she began to have headaches, loss of balance, muscular weakness, and frequent tiredness. I panicked because everything seemed to be pointing to polio infection. Then, a week after her continuous headaches began, she had to go to the hospital because there was something wrong with the pregnancy; she lost our daughter.

"I tried to get a polio test, and to find the cause of this tragic series of events, but the medical profession was extremely unhelpful. They laughed at me. I will never know why our son suddenly stopped growing or why his development regressed. I will never 
know why we lost our daughter. The only thing I am sure about is that the precursor to these events was the polio vaccine." [From an unsolicited e-mail received by the Thinktwice Global Vaccine Institute-www.thinktwice.com]

Today, fact sheets on polio published by the U.S. Department of Health and Human Services, warn parents that the inactivated polio vaccine (IPV) can cause "serious problems or even death... [49]" The company that manufactures the current inactivated polio vaccine warns that Guillain-Barré Syndrome, a debilitating ailment characterized by muscular incapacitation and nervous system damage, "has been temporally related to administration of another inactivated poliovirus vaccine [3:780]." And although this company makes the claim that "no causal relationship has been established," it also admits that "deaths have occurred" after vaccination of infants with IPV [3:780]. Yet, like the days of old, despite these "danger alerts," medical authorities continue to assure parents that the currently available inactivated polio vaccine is both safe and effective.

\section{How effective are polio vaccines?}

Polio is virtually nonexistent in the United States today. However, according to Dr. Robert Mendelsohn, medical investigator and pediatrician, there is no credible scientific evidence that the vaccine caused polio to disappear [50]. From 1923 to 1953, before the Salk killed-virus vaccine was introduced, the polio death rate in the United States and England had already declined on its own by 47 percent and 55 percent, respectively (Figure 4) [51]. Statistics show a similar decline in other European countries as well [51]. And when the vaccine did become available, many European countries questioned its effectiveness and refused to systematically inoculate their citizens. Yet, polio epidemics also ended in these countries [50].

Figure 4. The polio death rate was decreasing on its own before the vaccine was introduced

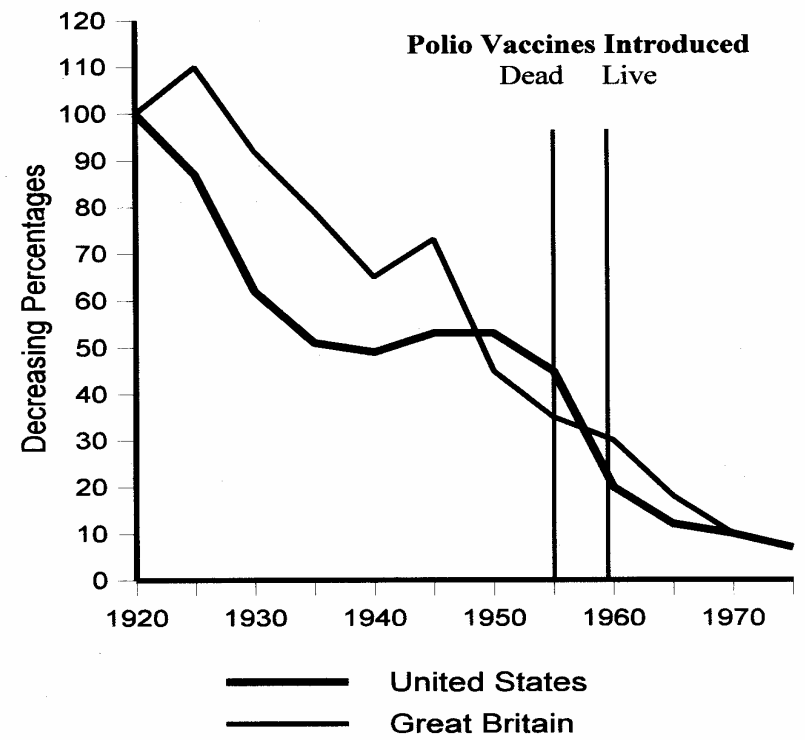

From 1923 to 1953, before the Salk killed-virus vaccine was introduced, the polio death rate in the United States and England had already declined on its own by 47 percent and 55 percent, respectively. Source: International Mortality Statistics (1981) by Michael Alderson.
The standards for defining polio were changed when the polio vaccine was introduced. The new definition of a polio epidemic required more cases to be reported. Paralytic polio was redefined as well, making it more difficult to confirm, and therefore tally, cases. Prior to the introduction of the vaccine the patient only had to exhibit paralytic symptoms for 24 hours. Laboratory confirmation and tests to determine residual paralysis were not required. The new definition required the patient to exhibit paralytic symptoms for at least 60 days, and residual paralysis had to be confirmed twice during the course of the disease. Also, after the vaccine was introduced cases of aseptic meningitis (an infectious disease often difficult to distinguish from polio) and coxsackie virus infections were more often reported as separate diseases from polio. But such cases were counted as polio before the vaccine was introduced. The vaccine's reported effectiveness was therefore skewed (Table 1 and Figure 5) [52,53].

Table 1. Polio or aseptic meningitis?

\begin{tabular}{lcc}
\hline \multicolumn{1}{c}{ Sample Months } & $\begin{array}{c}\text { Reported Cases } \\
\text { of Polio }\end{array}$ & $\begin{array}{c}\text { Reported Cases of } \\
\text { Aseptic Meningitis }\end{array}$ \\
\hline $\begin{array}{l}\text { July 1955 } \\
\text { (Before the new } \\
\text { polio definition was } \\
\text { introduced.) }\end{array}$ & 273 & 50 \\
July 1961 & 161 \\
(After the new polio \\
definition was in- \\
troduced.) \\
$\begin{array}{l}\text { September 1966 } \\
\text { (After the new polio } \\
\text { definition was in- } \\
\text { troduced) }\end{array}$ \\
$\begin{array}{l}\text { Cases of polio were more often reported as aseptic meningitis after the } \\
\text { vaccine was introduced, skewing efficacy rates. Source: The Los Angeles } \\
\text { County Health Index: Morbidity and Mortality, Reportable Diseases. }\end{array}$
\end{tabular}

\section{Figure 5. Polio cases were predetermined to decrease when the medical definition of polio was changed}

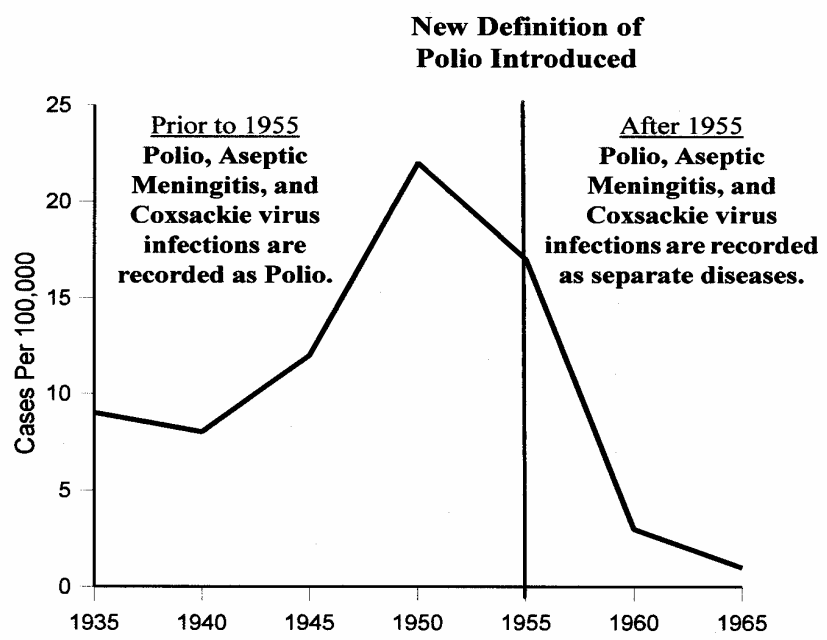

Source: Congressional Hearings, May 1962; and National Morbidity Reports taken from U.S. Public Health surveillance reports. 
The fact that dubious tactics were used to fabricate efficacy rates was corroborated by Dr. Bernard Greenberg, chairman of the Committee on Evaluation and Standards of the American Public Health Association during the 1950s. His expert testimony was used as evidence during Congressional hearings in 1962. He credited the "decline" of polio cases not to the vaccine, but rather to a change in the way doctors were required to report cases: "Prior to 1954 any physician who reported paralytic poliomyelitis was doing his patient a service by way of subsidizing the cost of hospitalization... two examinations at least 24 hours apart was all that was required... In 1955 the criteria were changed... residual paralysis was determined 10 to 20 days after onset of illness and again 50 to 70 days after onset... This change in definition meant that in 1955 we started reporting a new disease... Furthermore, diagnostic procedures have continued to be refined. Coxsackie virus infections and aseptic meningitis have been distinguished from poliomyelitis... Thus, simply by changes in diagnostic criteria, the number of paralytic cases was predetermined to decrease... blood streams as well. Apparently, SV-40 survived the formaldehyde Salk used to kill microbes that defiled his injectable vaccine [58,59]. Experts estimate that between 1954 and 1963, 30 million to 100 million Americans and perhaps another 100 million or more people throughout the world were exposed to SV-40 through illconceived polio eradication campaigns (Figure 6) [58-60].

Studies published in eminent journals throughout the world appear to confirm that SV-40 is a catalyst for many types of cancer [61-80]. It has been found in brain tumors and leukemia [69-80]. More recently, in 1996, Michele Carbone, a molecular pathologist at Chicago's Loyola University Medical Center, was able to detect $\mathrm{SV}-40$ in 38 percent of patients with bone cancer and in 58 percent of those with mesothelioma, a deadly type of lung cancer [81-83]. Carbone's research indicates that SV-40 blocks an important protein that normally protects cells from becoming malignant [83].

Figure 6. Polio vaccines and simian virus \#40 $[52: 96,97] "$

\section{Polio vaccines and cancer}

In 1959, Bernice Eddy, a brilliant government scientist working in Biologics at the National Institutes of Health, discovered that polio vaccines being administered throughout the world contained an infectious agent capable of causing cancer. When Eddy attempted to report her findings and halt production of these contaminated polio vaccines, her government superiors barred her from publicly revealing the problem. Instead, her lab and equipment were taken away and she was demoted $[54,55]$.

In 1960, Drs. Ben Sweet and M.R. Hilleman, pharmaceutical researchers for the Merck Institute for Therapeutic Research, were credited with discovering this infectious agent-SV-40, a monkey virus that infected nearly all rhesus monkeys, whose kidneys were used to produce polio vaccines. Hilleman and Sweet found SV-40 in all three types of Albert Sabin's live oral polio vaccine, and noted the possibility that it might cause cancer, "especially when administered to human babies [55,56]." According to Sweet, "It was a frightening discovery because, back then, it was not possible to detect the virus with the testing procedures we had... We had no idea of what this virus would do..." Sweet elaborated: "First, we knew that SV-40 had oncogenic (cancer-causing) properties in hamsters, which was bad news. Secondly, we found out that it hybridized with certain DNA viruses... such that [they] would then have SV-40 genes attached [to them]... When we started growing the vaccines, we just couldn't get rid of the SV-40 contaminated virus. We tried to neutralize it, but couldn't... Now, with the theoretical links to HIV and cancer, it just blows my mind [57]."

Further research into SV-40 uncovered even more disturbing information. This cancer-causing virus was not only ingested via Sabin's contaminated oral sugarcube vaccine, but was directly injected into people's

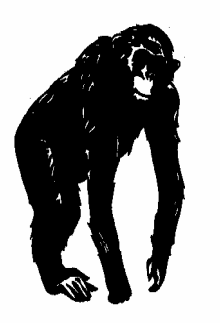

\section{Monkey kidneys are used to develop polio vaccines.}
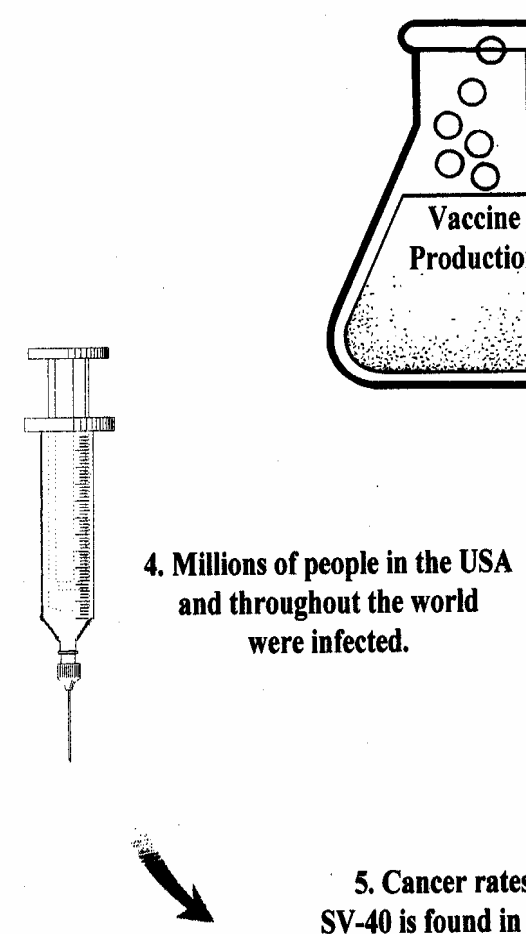

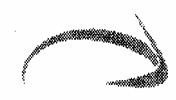
virus, thrived in monkey kidneys.
2. SV-40, a cancer-causing

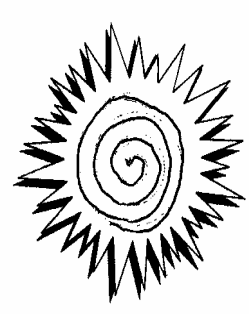

\section{Polio vaccines were contaminated.}

5. Cancer rates have increased. SV-40 is found in brain tumors, bone cancers, lung cancers, and leukemia.

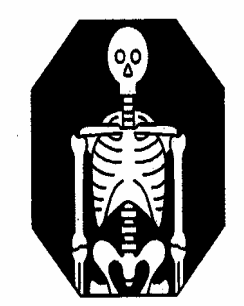


In 1998, a national cancer database was analyzed: 17 percent more bone cancers, 20 percent more brain cancers, and 178 percent more mesotheliomas were found in people who were exposed to SV-40-tainted polio vaccines [84]. The National Institutes of Health created a map showing the geographic distribution of contaminated stock [85]. Using this map, researchers found osteosarcoma bone tumor rates to be 10 times higher than normal in some regions where this tainted vaccine was used (Figure 7) [86,87].

\section{Figure 7. SV-40-tainted polio vaccines: zones of contamination}

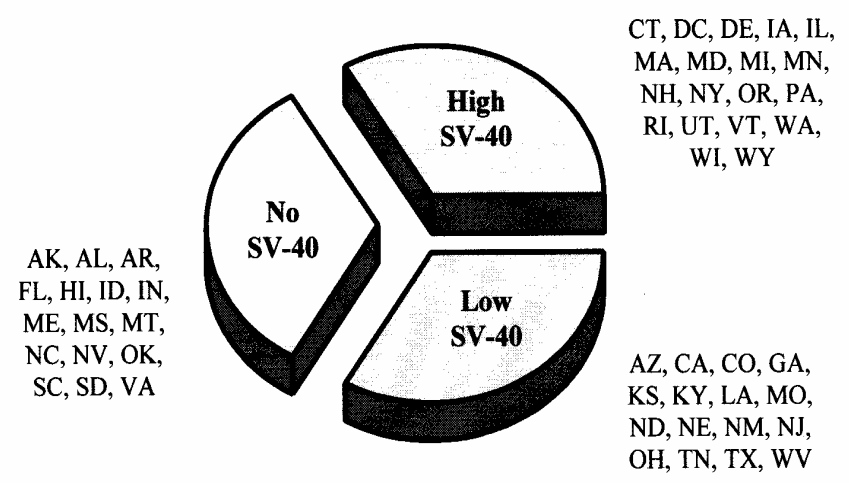

Between 1954 and 1963, up to 100 million Americans were inoculated with SV-40-contaminated polio vaccines. This chart shows areas of the country in 1955 where 10 million people received polio vaccines with either no, low, or high amounts of SV-40 in them. Source: National Institutes of Health.

Perhaps the most alarming aspect of this ongoing simian virus debacle can be found in other studies suggesting that SV-40, introduced to humans through the polio vaccine, can be passed from human to human and from mother to child. A study of nearly 59,000 women found that children of mothers who received the Salk vaccine between 1959 and 1965 had brain tumors at a rate 13 times greater than mothers who did not receive those polio shots [59:58;88;89].

Another study published in the U.S. medical journal Cancer Research found SV-40 present in 23 percent of blood samples and 45 percent of semen taken from healthy subjects [83:163;90]. Apparently, the virus is being spread sexually and from mother to child in the womb. According to biology and genetics professor Mauro Tognon, one of the study's authors, this would explain why brain, bone, and lung cancers are on the rise-a 30 percent increase in U.S. brain tumors alone over the past 25 years [83:163;90]—and why SV-40 was detected in brain tumors of children born after 1965 who presumably did not receive polio vaccines containing the virus $[83: 163 ; 90]$.

Despite official denials of any correlation between polio vaccines, SV-40, and increased cancer rates [91], by April 2001, 62 papers from 30 laboratories around the world had reported SV-40 in human tissues and tumors [84:10]. The virus was also discovered in pituitary and thyroid tumors, and in patients with kidney disease $[84: 10,13]$. Even the National Cancer Institute issued a statement that SV-40 "may be associated with human cancer [84:11;92]."

Studies yet to be conducted may provide additional clues about the link between contaminated polio vaccines, SV-40, and new diseases. But scientists have their hands full. The latest research has uncovered correlations between polio vaccines, another monkey virus, and AIDS.

\section{Polio vaccines and AIDS}

$\mathrm{SV}-40$, the cancer-causing monkey virus found in polio vaccines and administered to millions of unsuspecting people throughout the world, was just one of numerous simian viruses known to have contaminated polio vaccines [38:57,58;93;94]. "As monkey kidney culture is host to innumerable simian viruses, the number found varying in relation to the amount of work expended to find them, the problem presented to the manufacturer is considerable, if not insuperable," one early vaccine researcher wrote to a congressional panel studying the safety of growing live polio-virus vaccine in monkey kidneys [95]. "As our technical methods improve we may find fewer and fewer lots of vaccine which can be called free from simian virus [95]."

According to Harvard Medical School professor Ronald Desrosier, the practice of growing polio vaccines in monkey kidneys is "a ticking time bomb [83:159]." Evidently, some viruses can live inside monkeys without causing harm. But if these viruses were to somehow cross species and enter the human population, new diseases could occur. Desrosier continued: "The danger in using monkey tissue to produce human vaccines is that some viruses produced by monkeys may be transferred to humans in the vaccine, with very bad health consequences [83:159]." Desrosier also warns that testing can only be done for known viruses, and that our knowledge is limited to about " 2 percent of existing monkey viruses [83:159]." Craig Engesser, a spokesman for Lederle Laboratories, a large vaccine manufacturing company, acknowledged that "you can't test for something if you don't know it's there [96]."

Virus detection techniques were crude and unreliable during the $1950 \mathrm{~s}, 60 \mathrm{~s}$, and 70s when polio vaccines were initially produced and dispensed. It wasn't until the mid 1980s that new and more sophisticated testing procedures were developed [84:5;96]. That was when researchers discovered that about 50 percent of all African green monkeys-the primate of choice for making polio vaccines-were infected with simian immunodeficiency virus (SIV), a virus closely related to human immunodeficiency virus (HIV), the infectious agent thought to precede AIDS [97-100]. This caused some researchers to wonder whether HIVs may simply be SIVs "residing in and adapting to a human host [101]." It caused others to suspect that SIV may have mutated into HIV once it was introduced into the human population by way of contaminated polio vaccines [59:54+;96-100;102-104].

Vaccine authorities were so concerned about the possibility that SIV was a precursor to HIV, and that polio vaccines were the means of transmission from monkey to human, that The World Health Organization (WHO) convened two meetings of experts in 1985 to explore the data and consider their options $[100,105]$. After all, SIV was very similar to HIV and occurred naturally in the monkey species predominantly used by vaccine manufacturers $[98,100]$. Nevertheless, WHO concluded that the vaccines were safe and insisted that vaccination campaigns should continue unabated $[100,105]$.

Shortly thereafter, Japanese researchers conducted their own investigation and found that African green monkeys used to produce polio vaccines had antibodies against SIV [106]. The implication was clear: monkeys used to produce polio vaccines were 
natural carriers of a virus that looked and acted like HIV, the infectious agent linked to AIDS. In 1989, they recommended that monkeys infected with SIV not be used to make polio vaccines [106].

In 1990, wild chimpanzees in Africa were found to be infected with a strain of SIV that was nearly identical to HIV [107]. Some researchers called it "the missing link" to the origins of human immunodeficiency virus [108]. And since chimpanzees were used to test viruses for potential use in vaccines, and were kept in captivity by research laboratories, they could have been a source of vaccine contamination $[109,110]$. Scientific concerns were also heightened when researchers found some West Africans who were infected with an SIV-like virus that was a fundamental twin to HIV. They called it HIV-2, and like the initial HIV subtype, it was implicated in the development of AIDS [111]. According to Robert Gallo, an expert on the AIDS virus, some versions of the SIV monkey virus are virtually indistinguishable from some human variants of HIV: "The monkey virus is the human virus. There are monkey viruses as close to isolates of HIV-2 as HIV-2 isolates are to each other [59:106+]." In May 1991, virus-detection techniques were improved once again, and researchers found SIV DNA in the kidneys of infected monkeys [112]. Minced monkey kidneys were (and still are) used to produce the live polio vaccine [3;59:60]. SIV was also found in the cancer cells of an AIDS victim, and in other people as well [113-115]. To many researchers, this trail of evidence had become too persuasive to deny. Apparently, millions of people were infected with monkey viruses capable of causing AIDS [101], and this cross-species transfer most likely occurred by way of SIV-contaminated polio vaccines [59;84;96-100;102-104;116-119].

\section{Didn't AIDS originate in Africa?}

Most historians agree that AIDS originated in Africa [120]. But Salk tested his vaccine in the U.S., and Sabin's trials were conducted in Eastern Europe and the former Soviet Union [100]. If tainted polio vaccines were responsible for introducing SIV and HIV into humans, why did the initial cases of AIDS show up on this remote continent?

In March 1951, several years before Drs. Jonas Salk and Albert Sabin would scuffle over whose vaccine was the true prophylactic, Dr. Hilary Koprowski announced at a medical conference that he had become the first doctor in history to test a polio vaccine on humans. His "volunteers" included several institutionalized children with mental handicaps. They drank the vaccine in chocolate milk [121].

From 1957 to 1960, after years of tinkering with monkey kidneys and polio germs, Koprowski tested his own experimental polio vaccine on 325,000 equatorial Africans, including 75,000 citizens of Leopoldville, Belgian Congo (now Kinshasa, Zaire) [59:59;121]. Called by drums, rural natives traveled to local villages where they had a liquid vaccine squirted into their mouths [122]. Ninety-eight percent of the vaccine recipients were infants and toddlers [121]. The youngest children received 15 times the adult dosage [103:98]. Though Koprowski claimed he had the backing of the World Health Organization, WHO denied sanctioning the large-scale trials [123].

In 1959, Dr. Albert Sabin reported in the British Medical Journal that Koprowski's polio vaccine used in the African trials con- tained an "unidentified" cell-killing virus [124]. It was never identified. However, in 1986 the earliest known blood sample containing antibodies against HIV was traced back to 1959. The serum came from a patient visiting a clinic in Leopoldville [125]. There is no evidence that HIV infected humans before 1959 [126,127]. Gerald Myers, a genetic sequencing expert with Los Alamos National Laboratories in New Mexico, tracked the evolution of HIV and confirmed that today's major subtypes of the AIDS virus in humans appear to have arisen as recently as 1960 [128].

Koprowski's vaccine was not approved for human use, so it was discontinued in 1960 following the African trials [100]. Thus, it was only administered to inhabitants of the Belgian Congo, Rwanda and Burundi [104,121]—the precise area where high levels of HIV infection were identified by researchers 30 years later [129]. Furthermore, the AIDS virus is known to infect mucous cells, prevalent in the mouth [59:60]. The African vaccines were squirted into people's mouths. Could squirting an HIVcontaminated polio vaccine into people's mouths cause AIDS? According to Tom Folks, chief retrovirologist at the CDC, "Any time a person has a lesion in his mouth, then there could be transmission" of the virus [59:60]. Dr. Robert Bohannon of Baylor College of Medicine maintains that the process of squirting the polio vaccine into people's mouths would tend to aerosolize some of the liquid. Tiny drops could then go directly into the lungs, and from there to the blood cells susceptible to infection [59:60]. This would have been an efficient mode of HIV transmission [100].

Disease experts believe that the average time between HIV infection and the development of AIDS is 8-10 years [100]. If the African polio vaccine was indeed contaminated with SIV/HIV, initial outbreaks of AIDS would have occurred from the mid1960 s to early 1970 s. This period accurately coincides with the emergence of AIDS in equatorial Africa [130].

\section{Test the polio vaccines}

Authorities are reluctant to acknowledge the possibility that medical scientists, preoccupied with growing polio vaccines in virus-laden monkey kidneys, may have been responsible for bringing about the AIDS pandemic. For example, Dr. David Heymann, who heads the World Health Organization's Global Program on AIDS, flatly stated that "the origin of the AIDS virus is of no importance to science today [59:106+]." William Haseltine, a Harvard pathology professor and AIDS researcher also believes that any discussion about the origin of AIDS is distracting and nonproductive. "It's not relevant," and "I'm not interested in discussing it [59:106+]." Jonas Salk won't discuss the subject either. He is now working on an AIDS vaccine [59:55]. Albert Sabin believes "you can't hang Koprowski with that [59:60]." And Koprowski dismissed the idea with a laugh, then later claimed "this is a highly theoretical situation [59:106+]." However, samples of the polio vaccines used in Africa are kept in freezers at the Wistar Institute where Koprowski did much of his research. They could be tested [59:106+].

Tom Folks of the CDC thinks it's a good idea to test the seed stocks of polio because "any time we can learn more about the natural history [of AIDS], it helps us understand the pathogenesis and...the transmission [59:106+]." Robert Gallo also thinks it's important to determine whether a monkey virus sparked AIDS. Questions like this "are of more than academic interest because 
answering them may help avoid future zoonotic catastrophes-that is, transmission of disease from lower animals to humans [131]." Responding to these concerns, some AIDS researchers formally requested samples of the original polio vaccine seed stocks. But the government will neither release nor test them because there are "only a small number of vials" of the material, and tests "might use it all up [59:108]."

\section{AIDS within the Gay community}

If AIDS originated in Africa via contaminated polio vaccines, how did this disease spread to male homosexuals in America? In 1974, clinics in New York and California began experimental treatments for gay men afflicted with herpes. Therapy consisted of multiple doses of the live polio vaccine [132]. As noted earlier, this vaccine was produced in the kidneys of the African Green monkey, a known reservoir for simian immunodeficiency virus (SIV), a likely precursor to HIV [59;84;97-104]. Beginning in the early 1980s, simultaneous outbreaks of Kaposi sarcoma and serious opportunistic infections (later associated with AIDS) were reported among homosexual men, especially in New York City, San Francisco, and Los Angeles [99]. This time span coincides with the average incubation period between HIV infection and the development of AIDS [100].

In 1982, the CDC concluded that such outbreaks "strongly suggests the occurrence of a single epidemic of underlying immunosuppression... [133]" The following year, HIV was identified as the causative agent [99]. And in 1992, Lancet published the first scientific explanation showing how repeated doses of SIVcontaminated polio vaccines may have seeded HIV among American homosexual men [99].

\section{AIDS with no identified risk factor (NIR)}

Another unusual event occurred in the 1980s. Hundreds of people diagnosed with AIDS had no identified risk factor (NIR) [134]. They did not engage in risky behaviors related to AIDS infection. The CDC also listed numerous children as NIR [134]. Some parents believe HIV-contaminated polio vaccines infected their loved ones [135].

On February 12, 1994, Bruce Williams filed a civil suit against the American Cyanamid Company, claiming its polio vaccine caused his daughter's illness. The suit alleges that "the live oral poliovirus vaccine was produced, tested, and approved by the United States Food and Drug Administration pursuant to measures inconsistent with accepted standards of medical practice." The lawsuit also asserts that "the product was FDA approved despite the known presence of contaminants, including retroviruses such as HIV [136]."

Walter Kyle, the Williams' lawyer, identified the specific lots of vaccine the child received, but the CDC and federal health officials have refused to test them [134:106]. Kyle believes "The CDC could disprove my entire hypothesis by testing the vaccines they have in their possession. The fact that they haven't done so is evidence there's something wrong with the vaccine [134:106]."

Some researchers believe the true number of NIR cases could be in the thousands [134,137]. When health officials examine people with AIDS, they try to identify a risk factor. If a patient admits he once had unprotected sex, that becomes his factor, even though there's no proof that is how he was infected [134].
The evidence implicating polio vaccines grown in monkey kidneys with our current epidemics of cancer and AIDS continues to grow. But what if polio vaccines were produced in cow serum? Would that make a difference?

\section{Polio vaccines and Mad Cow disease}

Mad cow disease, or bovine spongiform encephalopathy (BSE) is a progressive neurological disorder of cattle. Infected cows lose weight, drool, arch their backs, wave their heads, teeter back and forth, threaten other cows, act crazy, and eventually die. The first case of the disease was observed in 1984. Since then, BSE has killed more than 200,000 cows [138].

Mad cow disease is related to scrapie, a similar disease afflicting sheep [139]. In fact, authorities believe it spread to cows from sheep when they were fed scrapie-infected bone meal [139]. Cruetzfeldt-Jakob disease (CJD) and vCJD (a newly discovered variant) are the human equivalents of mad cow disease [139]. They cause a comparable wasting of the brain leading to muscle incoordination, sensory loss, and mental confusion [139]. It is always fatal. There is no known cure [138:54].

There is very strong evidence that mad cow disease and the newly discovered variant of Cruetzfeldt-Jakob disease are caused by the same infectious agent. For example, a 1996 study showed that monkeys injected with BSE developed symptoms remarkably similar to vCJD [140]. Another study showed that BSE and vCJD had similar molecular characteristics-unlike "classical" CJD [141]. Two later studies, one published in 1997, the other in 1999, appear to confirm that BSE from cattle causes vCruetzfeldt-Jakob disease in humans [142,143]. Researchers think that mad cow disease can be passed from cows to humans if they ingest BSEinfected beef $[138: 56 ; 144 ; 145]$, or if they receive vaccines contaminated with BSE [145-148].

BSE associated infectious agents are capable of contaminating polio vaccines because they are not only grown in monkey kidneys, but in calf serum as well [3]. In fact, many parts of the cow are used in vaccine production. Glycerol is derived from cow fat; gelatin and amino acids come from cow bones; and the growth medium for viruses and other microorganisms may require cow skeletal muscle, enzymes, and blood [139].

Authorities knew that vaccines could be infected with BSE associated transmissible agents as early as 1988. Yet, in England, vaccine manufacturers waited months before switching to cows less likely to be infected, and refused to remove current stock off the shelves and out of doctor's offices until it was all sold, or expired five years later towards the end of 1993 [146]. One outraged legislator declared that "the Department of Health was potentially criminally negligent in not requiring the immediate withdrawal or cessation of use of vaccines from potentially contaminated sources [146]." Despite nationwide apprehension, manufacturers continued to disregard European guidelines [150]. Finally, in October 2000, the Department of Health became so concerned about the likelihood of children being infected with BSE-contaminated vaccines and falling prey to vCruetzfeldt-Jakob disease (dozens of people, including children, had already contracted it) [151] that they issued a recall of hundreds of thousands of polio vaccines made using fetal bovine serum extracted from British cows $[139,148,152]$. 
In the United States, authorities waited until December 1993 before issuing a "recommendation" that U.S. manufacturers not use bovine material from countries reporting BSE [153]. The FDA issued a second warning to manufacturers in 1996 informing them to "take whatever steps are necessary to reduce potential risk of transmission of BSE agent $[139,147] . "$ But in March 2000, the FDA discovered that its "recommendations" were ignored. Vaccines were still being made in bovine materials obtained from countries reporting BSE [147].

Americans have something else to be concerned about as well. Although U.S. cows do not exhibit "mad cow symptoms," every year in the United States tens of thousands of cattle are severely incapacitated; they cannot stand and walk on their own. Farm Sanctuary, a national non-profit organization dedicated to halting irresponsible agricultural practices, believes that these "downed" animals may harbor a new variant of BSE, and is critical of the Food and Drug Administration's BSE surveillance efforts [154]. Despite early warning signs, downed cows are not examined for a new variant of BSE, and have not been ruled out of vaccine production [154].

Dr. Richard Marsh of the Department of Animal Health and Biomedical Sciences at the University of Wisconsin, Madison, conducted research providing evidence that downed cattle in the U.S. may harbor a new variant of mad cow disease. He inoculated cows with TME, a variant of BSE. They became "downed" instead of "mad" [155]. Other scientists inoculated cows with scrapie from U.S. sheep. They, too, became "downed" instead of "mad" [156]. Responding to the FDA's apparent indifference, Farm Sanctuary issued the following statement: "We are distressed that economic priorities have tended to take precedence over the health of consumers. We are also concerned that, like in Britain, a powerful economic incentive exists to ignore evidence that BSE, or a variant of BSE, exists in the U.S. We urge the FDA to examine the scientific evidence regarding BSE carefully and to act in the interest of American consumers [154]." Regardless, the FDA did not modify its BSE surveillance policies, and vaccines made in bovine material obtained from countries reporting BSE were not going to be removed from the market for at least another year, until 2002-after all existing stock had been purchased and consumed $[139,147]$.

\section{More animal viruses}

Thousands of viruses and other potentially infectious microorganisms thrive in monkeys and cows, the preferred animals for making polio vaccines [83:159]. SV-40, SIV, and BSE associated transmissible agents are just three of the disease-causing agents researchers have isolated. For example, scientists have known since 1955 that monkeys host the "B" virus, foamy agent virus, haemadsorption viruses, the LCM virus, arboviruses, and more [157]. Bovine immunodeficiency virus (BIV), similar in genetic structure to HIV, was recently found in some cows [103:100].

In 1956, respiratory syncytial virus (RSV) was discovered in chimpanzees [158]. According to Dr. Viera Scheibner, who studied more than 30,000 pages of medical papers dealing with vaccination, RSV viruses "formed prominent contaminants in polio vaccines, and were soon detected in children [159]." They caused serious cold-like symptoms in small infants and babies who received the polio vaccine [159]. In 1961, the Journal of the Ameri- can Medical Association published two studies confirming a causal relationship between RSV and "relatively severe lower respiratory tract illness [160]." The virus was found in 57 percent of infants with bronchiolitis or pneumonia, and in 12 percent of babies with a milder febrile respiratory disease [161]. Infected babies remained ill for three to five months [161]. RSV was also found to be contagious, and soon spread to adults where it has been linked to the common cold [162].

Today, RSV infects virtually all infants by the age of two years, and is the most common cause of bronchiolitis and pneumonia among infants and children under one year of age [163]. It also causes severe respiratory disease in the elderly [164]. RSV remains highly contagious and results in thousands of hospitalizations every year; many people die from it [165]. Ironically, scientists are developing a vaccine to combat RSV [166] -the infectious agent that very likely entered the human population by way of a vaccine [159].

Dr. John Martin, a professor of pathology at the University of Southern California, has been warning authorities since 1978 that other dangerous monkey viruses could be contaminating polio vaccines. In particular, Martin sought to investigate simian cytomegalovirus (SCMV), a "stealth virus" capable of causing neurological disorders in the human brain. The virus was found in monkeys used for making polio vaccines. The government rebuffed his efforts to study the risks [83:159-61]. However, in 1995, Martin published his findings implicating the African green monkey as the probable source of SCMV isolated from a patient with chronic fatigue syndrome [167].

In 1996, Dr. Howard B. Urnovitz, a microbiologist, founder and chief science officer of Calypte Biomedical in Berkeley, California spoke at a national AIDS conference where he revealed that up to 26 monkey viruses may have been in the original Salk vaccines. These included the simian equivalents of human echo virus, coxsackie, herpes (HHV-6, HHV-7, and HHV-8), adenoviruses, Epstein-Barr, and cytomegalovirus [168-170]. Urnovitz believes that contaminated Salk vaccines given to U.S. children between 1955 and 1961 may have set this generation up for immune system damage and neurological disorders. He sees correlations between early polio vaccine campaigns and the sudden emergence of human T-cell leukemia, epidemic Kaposi's sarcoma, Burkitt's lymphoma, herpes, Epstein-Barr and chronic fatigue syndrome [168:1].

Urnovitz also discussed "jumping genes" - normal genes that may recombine with viral fragments to form new hybrid viruses called chimeras. He believes that this is exactly what happened when monkey viruses and human genes were brought together during early polio vaccine campaigns. And because the chimera "has the envelope of a normal human gene," typical cures won't work. How do you develop a vaccine or other antidote against the body's own DNA [168:1-4;171]?

\section{Mutated polio strains}

Several years ago, the World Health Organization launched the Global Polio Eradication Initiative, with 2000 as its target date for eliminating the disease. However, by 2000 it became clear that not only was polio still around, but new strains of the diseasederived from the vaccine itself-were emerging [172]. Researchers first noticed something unusual in 1983. Outbreaks of polio in 
Egypt were being caused by a "vaccine-derived" polio virus [173]. In 1993, Dr. Radu Crainic of the Pasteur Institute, discovered that strains of the polio virus have the ability to spontaneously recombine with themselves and create new strains. Crainic showed that if you vaccinate a child with polio strains 1,2 , and 3 , you can produce a new strain, strain 4, out of the child's stool. Crainic concluded that the polio vaccine creates favorable conditions contributing to the evolution of viral "recombinations" [174].

In October 2000, virologist Hiromu Yoshida of Japan's National Institute of Infectious Diseases in Tokyo reported finding a new infectious polio virus in Japanese rivers and sewage. Genetic sequencing confirmed that the virus had mutated from the polio vaccine and regained much of its original virulence [175]. According to Yoshida, it poses a "persistent environmental threat [172]."

In December 2000, researchers reported on a polio outbreak in Haiti and the Dominican Republic that resulted in numerous cases of flaccid paralysis [173]. Laboratory examinations confirmed health authorities' worst suspicions: the disease was caused by "an unusual viral derivative" of the polio vaccine. The virus demonstrates genetic similarity to the parent vaccine strain, "but it has assumed the neurovirulence and transmissibility" of the wild polio virus [173]. Health officials are obviously concerned, "because a wild poliovirus has not circulated in the Western Hemisphere since 1991 ," and if the newly mutated polio virus spreads, it could cause new epidemics of the disease (Figure 8) [173].

\section{Figure 8. Polio eradication with vaccines: a vicious cycle?}

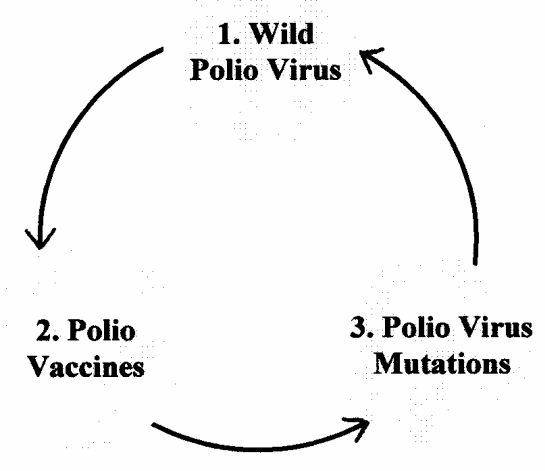

The wild polio virus brought about the development of polio vaccines, which spawned mutations of the polio virus, resulting in new "vaccinederived" wild polio viruses. Source: Virology 1993; 196:199-208; Lancet (October 28, 2000); Reuters Medical News (December 4, 2000)

\section{How is today's polio vaccine produced?}

Despite the polio vaccine's long history of causing polio, and the manufacturer's inability to protect the public from dangerous microorganisms that perpetually contaminate their ever growing repertoire of "new and improved" products, the currently available inactivated, or "killed-virus" polio vaccine continues to be manufactured in much the same way as earlier versions. Animal matter and questionable drugs are still used. In the United States, today's polio vaccine is a sterile suspension of three types of poliovirus. "The viruses are grown in cultures of a continuous line of monkey kidney cells...supplemented with newborn calf serum..." The vaccine also contains two antibiotics (neomycin and streptomycin), in addition to formaldehyde as a preservative [3].
In Canada, the inactivated polio vaccine is produced in "human diploid cells" instead of monkey kidneys [83:163]. Some researchers believe this is a safer alternative. According to Barbara Loe Fisher, president of the National Vaccine Information Center in Vienna, Virginia, "With mounting evidence that cross-species transfer of viruses can occur, the United States should no longer be using animal tissues to produce vaccines [91]." However, Dr. Arthur Levine of the National Institutes of Health believes that making polio vaccines using human cells isn't risk-free either, "because they must be tested for human infections [176]."

\section{Are positive changes possible?}

Government officials worry that even debating the issue will frighten parents. Levine probably speaks for many people within the vaccine industry when he declares: "We do a grave disservice to the public if we were now to question the safety of the current polio vaccines... [176]" But Barbara Loe Fisher would like to see changes in the way vaccine safety is governed. She believes that agencies like the FDA have an inherent conflict of interest because of their mandate to promote universal vaccination on the one hand and regulate vaccine safety on the other. "Who's minding the store when the FDA has allowed drug companies to produce vaccines grown on contaminated monkey kidneys?" Fisher asks. "What happened to protecting the public health [60]?" Dr. John Martin agrees. He believes that we need to immediately determine the prevalence of stealth viruses of simian origin in the United States, and whether they may be contributing to chronic immune system and brain disorders in children and adults [177]. Dr. Urnovitz is even more resolute in his convictions. He thinks that an extensive study of human exposure to simian microbes is long overdue. "Half of the people in this country are baby boomers who were born between 1941 and 1961 and are at high risk for having been exposed to polio vaccines contaminated with monkey viruses. Are we just a time bomb waiting to happen, waiting to develop lupus, Alzheimer's and Parkinson's disease [168:4,5;169]?" Urnovitz also challenged medical science to prove him wrong. "What we are saying here is that there is a strong probability that no human retroviruses existed before the polio vaccines... You have to realize that if you mess around with nature, you're going to pay the price... The objective here is a better, healthier world... $[168: 4,5 ; 169 ; 171] "$

\section{References}

[1] Okonek BM, et al. Development of polio vaccines. Access Excellence Classic Collection, February 16, 2001:1. www.accessexcellence.org/AE/AEC /CC/polio.html

[2] Volk WA, et al. Basic Microbiology, $4^{\text {th }}$ edition. Philadelphia, PA: J.B. Lippincott Co., 1980:455.

[3] Physician's Desk Reference (PDR); $55^{\text {th }}$ edition. Montvale, NJ: Medical Economics, 2001:778.

[4] Burnet, M., et al. The Natural History of Infectious Disease New York, NY: Cambridge University Press, 1972:16.

[5] Neustaedter R. The Vaccine Guide. Berkeley, California: North Atlantic Books, 1996:107-8

[6] Baby Center. The Polio Vaccine (0-12 months). www.babycenter. com/refcap/155.html?CP_bid=

[7] Moskowitz R. Immunizations: The Other Side. Mothering Spring 1984:36.

[8] Houchaus. Ueber Poliomyelitis acuta. Munch Med Wochenschr 1909; 56:2353-55.

[9] Lambert SM. A yaws campaign and an epidemic of poliomyelitis in Western Samoa. J Trop Med Hyg 1936; 39:41-6. 
[10] Lindsay KW, et al. Neurology and Neurosurgery Illustrated. Edinburgh/London/New York: Churchill Livingston, 1986:100. Figure 15.2. Polio incidence rates obtained from National Morbidity Reports.

[11] McCloskey BP. The relation of prophylactic inoculations to the onset of poliomyletis. Lancet, April 18, 1950:659-63.

[12] Geffen DH. The incidence of paralysis occurring in London children within four weeks after immunization. Med Officer 1950;83:137-40.

[13] Martin JK. Local paralysis in children after injections. Arch Dis Child $1950 ; 25: 1-14$.

[14] Hill AB, et al. Inoculation and poliomyelitis. A statistical investigation in England and Wales in 1949. British Medical Journal 1950; ii:1-6.

[15] Medical Research Council Committee on Inoculation Procedures and Neurological Lesions. Poliomyelitis and prophylactic inoculation. Lancet 1956; ii:1223-31.

[16] Sutter RW, et al. Attributable risk of DTP (Diphtheria and Tetanus Toxoids and Pertussis Vaccine) injection in provoking paralytic poliomyelitis during a large outbreak in Oman. Journal of Infectious Diseases 1992; 165:444-9.

[17] Strebel PM, et al. Intramuscular injections within 30 days of immunization with oral poliovirus vaccine - a risk factor for vaccine-associated paralytic poliomyelitis. New England J of Med, February 23, 1995:500+.

[18] Editorial. Provocation paralysis. Lancet 1992; 340:1005.

[19] Wyatt HV. Provocation poliomyelitis: neglected clinical observations from 1914-1950. Bulletin of Historical Medicine 1981; 55:543-57.

[20] Townsend-Coles, W.F and Findlay, G.M. Poliomyelitis in relation to intramuscular injections of quinine and other drugs. Trans $R$ Soc Trop Med Hyg 1953; 47:77-81.

[21] Guyer B, et al. Injections and paralytic poliomyelitis in tropical Africa. Bull WHO 1980; 58:285-91.

[22] Bodian D. Viremia in experimental poliomyelitis. II. Viremia and the mechanism of the 'provoking' effect of injections of trauma. Amer J Hyg $1954 ; 60: 358-70$

[23] Wyatt HV. Incubation of poliomyelitis as calculated from time of entry into the central nervous system via the peripheral nerve pathways. Rev Infect Dis $1990 ; 12: 547-56$.

[24] Wyatt HV, et al. Unnecessary injections and paralytic poliomyelitis in India. Trans R Soc Trop Med Hyg 1992; 86:546-9.

[25] Chandra RK. Reduced secretory antibody response to live attenuated measles and poliovirus vaccines in malnourished children. British Medical Journal 1975; ii:583-5.

[26] McBean E. The Poisoned Needle. Mokelumne Hill, California: Health Research, 1957:116.

[27] Sandler B. American Journal of Pathology, January 1941.

[28] Sandler B. Diet Prevents Polio (Milwaukee: Lee Foundation for Nutritional Research, 1951).

[29] Allen H. Don't Get Stuck: The Case Against Vaccinations. (Oldsmar, Florida: Natural Hygiene Press, 1985:166.

[30] Harry NM. The recovery period in anterior poliomyelitis. British Medical Journal 1938; 1:164-7.

[31] Sharrard W. Muscle recovery in poliomyelitis. J Bone Joint Surgery 1955; 37B:63-79.

[32] Affeldt JE, et al. Functional and vocational recovery in severe poliomyelitis. Clin Orthop 1958; 12:16-21.

[33] Hollenberg C, et al. The late effects of spinal poliomyelitis. Can Med Assoc $J$ 1959; 81:343-6.

[34] Ramlow, J., et al. Epidemiology of the post-polio syndrome. American Journal of Epidemiology 1992;136:783.

[35] A Science Odyssey: People and Discoveries. Salk produces polio vaccine.www.pbs.org/wgbh/aso/databank/entries/dm52sa.html

[36] Strebel PM., et al. Epidemiology of poliomyletis in U.S. one decade after the last reported case of indigenous wild virus associated disease, Clinical Infectious Diseases CDC, February 1992:568-79.

[37] Gorman C. When the vaccine causes the polio. Time October 30, 1995:83.

[38] Shaw D. Unintended casualties in war on polio. Philadelphia Inquirer June 6, 1993:A1.

[39] Morbidity and Mortality Weekly Report (MMWR): CDC. 2000; 49:1-22.

[40] Reuters Medical News. CDC publishes Updated Poliomyelitis prevention recommendations for the U.S., May 22, 2000. www.id.medscape.com /reuters/prof/2000/05/05.22/20000522plcy001.html

[41] The Associated Press. Polio cases caused by vaccine. The Santa Fe New Mexican, January 31, 1997.

[42] Data taken from government statistics, as reported in an Associated Press dispatch from Boston, August 30, 1955.
[43] As reported by Saul Pett in an Associated Press dispatch from Pittsburgh, October 11, 1954.

[44] Washington Post, September 24, 1976.

[45] American Academy of Pediatrics, Report of the Committee on Infectious Diseases: 1986 (Elk Grove Village, Illinois: AAP):284-5.

[46] Institute of Medicine. An evaluation of poliomyelitis vaccine policy options. IOM Publication 88-04 (Washington DC: National Academy of Sciences, 1988).

[47] Vaccine Adverse Event Reporting System (VAERS), Rockville, MD.

[48] IOS. The Polio vaccine coverup-OPV Vaccine Report: Document \#14. www.ios.com/ w1066/poliov6.html

[49] U.S. Department of Health and Human Services. Polio: What You Need to Know, Atlanta, GA: CDC, October 15, 1991:3.

[50] Mendelsohn R. How to Raise a Healthy Child...In Spite of Your Doctor. (Ballantine Books, 1984:231.

[51] Alderson M. International Mortality Statistics, Washington, DC: Facts on File, 1981:177-8.

[52] Hearings Before the Committee on Interstate and Foreign Commerce, House of Representatives, $87^{\text {th }}$ Congress, $2^{\text {nd }}$ Session on HR 10541. May 1962:94-112.

[53] Los Angeles County Health Index: Morbidity and Morality, Reportable Diseases.

[54] O’Hern M. Profiles: Pioneer Women Scientists. Bethesda, MD: National Institutes of Health.

[55] Curtis T, Manson P. Scientist's Polio Fear Unheeded: How U.S. Researcher's Warning Was Silenced. The Houston Post 1992:A1 and A12.

[56] Sweet BH, Hilleman MR. The Vacuolating Virus: SV-40. As cited in The polio vaccine and simian virus 40 by Moriarty, T.J. www.chronicillnet.org/ online/bensweet.html

[57] Moriarty T.J. The polio vaccine and simian virus 40 . Online News Index. www.chronicillnet.org/online/bensweet.html

[58] Shah K, Nathanson N. Human exposure to SV40. American Journal of Epidemiology, 1976;103:1-12.

[59] Curtis T. The origin of AIDS: A startling new theory attempts to answer the question 'Was it an act of God or an act of man' Rolling Stone, March 19, 1992:57.

[60] Bookchin D, Schumaker J. Tainted Polio Vaccine Still Carries Its Threat 40 Years Later. The Boston Globe, January 26, 1997.

[61] Innis MD. Oncogenesis and poliomyelitis vaccine. Nature, 1968;219:9723.

[62] Soriano F, et al. Simian virus 40 in a human cancer. Nature, 1974; 249:421-4.

[63] Weiss AF, et al. Simian virus 40-related antigens in three human meningiomas with defined chromosome loss. Proceedings of the National Academy of Science, 1975;72(2):609-13.

[64] Scherneck S, et al. Isolation of a SV-40-like papovavirus from a human glioblastoma. International Journal of Cancer, 1979;24:523-31.

[65] Stoian M, et al. Possible relation between viruses and oromaxillofacial tumors. II. Research on the presence of SV40 antigen and specific antibodies in patients with oromaxillofacial tumors. Virologie, 1987;38:35-40.

[66] Stoian M, et al. Possible relation between viruses and oromaxillofacial tumors. II. Detection of SV40 antigen and of anti-SV40 antibodies in patients with parotid gland tumors. Virologie, 1987;38:41-6.

[67] Bravo MP, et al. Association between the occurrence of antibodies to simian vacuolating virus 40 and bladder cancer in male smokers. Neoplasma, 1988;35:285-8.

[68] O'Connell K, et al. Endothelial cells transformed by SV40 T-antigen cause Kaposi's sarcoma-like tumors in nude mice. American Journal of Pathology, 1991;139(4):743-9.

[69] Weiner LP, et al. Isolation of virus related to SV40 from patients with progressive multifocal leukoencephalopathy. New England Journal of Medicine, 1972;286:385-90.

[70] Tabuchi K. Screening of human brain tumors for SV-40-related T-antigen. International Journal of Cancer 1978;21:12-7.

[71] Meinke W, et al. Simian virus 40-related DNA sequences in a human brain tumor. Neurology 1979;29:1590-4.

[72] Krieg P, et al. Episomal simian virus 40 genomes in human brain tumors. Proceedings of the National Academy of Science 1981; 78:6446-50.

[73] Krieg P, et al. Cloning of SV40 genomes from human brain tumors. Virology 1984;138:336-40

[74] Geissler E. SV40 in human intracranial tumors: passenger virus or oncogenic 'hit-and-run' agent? Z Klin Med, 1986;41:493-5. 
[75] Geissler E. SV40 and human brain tumors. Progress in Medical Virology, 1990;37:211-22.

[76] Bergsagel DJ, et al. DNA sequences similar to those of simian virus 40 in ependymomas and choroid plexus tumors of childhood. New England Journal of Medicine, 1992;326:988-93.

[77] Martini, M., et al. Human brain tumors and simian virus 40. Journal of the National Cancer Institute, 1995;87(17):1331.

[78] Lednicky JA, et al. Natural Simian Virus 40 Strains are Present in Human Choroid Plexus and Ependymoma Tumors. Virology, 1995;212(2):710-7.

[79] Tognon M, et al. Large T Antigen Coding Sequence of Two DNA Tumor Viruses, BK and SV-40, and Nonrandom Chromosome Changes in Two Gioblastoma Cell Lines. Cancer Genetics and Cytogenics, 1996;90(1): 1723.

[80] Vilchez RA, et al. Association between simian virus 40 and non-hodgkin lymphoma. Lancet, (March 9, 2002), 359: 817-23.

[81] Carbone, M., et al. SV-40 Like Sequences in Human Bone Tumors. Oncogene, 1996;13(3):527-35.

[82] Pass, HI, Carbone, M., et al. Evidence For and Implications of SV-40 Like Sequences in Human Mesotheliomas. Important Advances in Oncology, 1996:89-108.

[83] Rock, Andrea. The Lethal Dangers of the Billion Dollar Vaccine Business, Money, December 1996:161.

[84] Carlsen, W. Rogue virus in the vaccine: Early polio vaccine harbored virus now feared to cause cancer in humans. San Francisco Chronicle, July 15, 2001:7. Research by Susan Fisher, epidemiologist, Loyola University Medical Center.

[85] National Institutes of Health. Zones of Contamination: Globe Staff Graphic.

[86] Bookchin D, Schumacher J. Tainted polio vaccine still carries its threat 40 years later. The Boston Globe, January 26, 1997.

[87] SV-40 Contamination of Polio Vaccine. Well Within Online, (February 3, 2001, updated). www.nccn.net/ $\sim$ wwithin/polio.htm

[88] Rosa FW, et al. Absence of antibody response to simian virus 40 after inoculation with killed-poliovirus vaccine of mothers offspring with neurological tumors. New England Journal of Medicine, 1988;318:1469.

[89] Rosa FW, et al. Response to: Neurological tumors in offspring after inoculation of mothers with killed poliovirus vaccine. New England Journal of Medicine, 1988, 319:1226.

[90] Martini F, et al. SV-40 Early Region and Large T Antigen in Human Brain Tumors, Peripheral Blood Cells, and Sperm Fluids from Healthy Individuals. Cancer Research, 1996;56(20):4820-5.

[91] Fisher, Barbara. Vaccine safety consumer group cites conflict of interest in government report on cancer and contaminated polio vaccine link. National Vaccine Information Center (NVIC); Press Release, January 27, 1998.

[92] National Cancer Institute (June 2001).

[93] Koprowksi H. Tin anniversary of the development of live virus vaccine. Journal of the American Medical Association 1960;174:972-6.

[94] Hayflick L, Koprowski H, et al. Preparation of poliovirus vaccines in a human fetal diploid cell strain. American J Hyg 1962;75:240-58.

[95] Koprowski H. In a letter sent to the Congressional Health and Safety Subcommittee, April 14, 1961.

[96] Curtis T. Expert says test vaccine: backs check of polio stocks for AIDS virus. The Houston Post, March 22, 1992:A-21.

[97] Essex M, et al. The origin of the AIDS virus. Scientific American, 1988; 259:64-71.

[98] Karpas A. Origin and Spread of AIDS. Nature, 1990; 348:578.

[99] Kyle WS. Simian retroviruses, poliovaccine, and origin of AIDS. Lancet, 1992; 339:600-1.

[100] Elswood BF, Stricker RB. Polio vaccines and the origin of AIDS. Medical Hypothesis, 1994:42:347-54.

[101] Myers G, et al. The emergence of simian/human immunodeficiency viruses. AIDS Res Human Retro 1992:8:373-86.

[102] Workshop on Simian Virus-40 (SV-40): A Possible Human Polyomavirus National Vaccine Information Center, January 27-28, 1997. www.909shot. com/polio197.htm (Includes a summary of evidence presented at the Eighth Annual Houston Conference on AIDS.)

[103] Martin B. Polio vaccines and the origin of AIDS: The career of a threatening idea. Townsend Letter for Doctors, January 1994:97-100.

[104] Curtis T. Did a polio vaccine experiment unleash AIDS in Africa? The Washington Post, April 5, 1992:C3+.

[105] World Health Organization. T-lymphotropic retroviruses of nonhuman primates. WHO informal meeting. Weekly Epidemiology Records, 1985; 30:269-70.
[106] Ohta Y, et al. No evidence for the contamination of live oral poliomyelitis vaccines with simian immunodeficiency virus. AIDS, 1989; 3:183-5.

[107] Huet T, et al. Genetic organization of a chimpanzee lentivirus related to HIV-1. Nature, 1990; 345:356-9.

[108] Desrosiers RC. HIV-1 origins: A finger on the missing link. Nature, 1990;345:288-9.

[109] Sabin AB. Properties and behavior of orally administered attenuated poliovirus vaccine. Journal of the American Medical Association, 1957; 164:1216-23.

[110] Plotkin SA, Koprowski H, et al. Clinical trials in infants of orally administered poliomyelitis viruses. Pediatrics 1959;23:1041-62.

[111] Barin F, et al. Serological evidence for virus related to simian Tlymphotropic retrovirus III in residents of West Africa. Lancet 1985; ii:1387-9.

[112] Hirsch VM, Zack PM, Vogel AP, Johnson PR. Simian immunodeficiency virus infection of macaques: End-stage disease is characterized by widespread distribution of proviral DNA in tissues. Journal of Infectious Disease, 1991; 163(5):976-88.

[113] Bohannon RC, et al. Isolation of a Type D retrovirus from B-cell lymphomas of a patient with AIDS. Journal of Virology, 1991;65(11):5663-72.

[114] Khabbaz RF, et al. Simian immunodeficiency virus needlestick accident in a laboratory worker. Lancet, 1992;340:271-3.

[115] Gao F, et al. Human infection by genetically diverse SIVsm-related HIV-2 in West Africa. Nature, 1992;358:495-9.

[116] Giunta S, et al. The primate trade and the origin of AIDS viruses. Nature, 1987;329:22.

[117] Seale J. Crossing the species barrier-viruses and the origins of AIDS in perspective. J R Soc Med, 1989;82:519-23.

[118] Lecatsas G. Origin of AIDS. Nature, 1991;351:179.

[119] Gilks C. Monkeys and malaria. Nature, 1991;354:262.

[120] Grmek MD. History of AIDS: Emergence and Origin of a Modern Pandemic. Princeton, NJ: Princeton University Press, 1990.

[121] Koprowski H. Historical aspects of the development of live virus vaccine in poliomyelitis. British Medical Journal, 1960;ii:85-91.

[122] Lebrun A, et al. Vaccination with the CHAT strain of Type 1 attenuated poliomyelitis virus in Leopoldville, Belgian Congo. Bulletin of the World Health Organization, 1960;22:203-13.

[123] Klein A. Trial by Fury. New York, NY: Charles Scribner's Sons, 1972.

[124] Sabin AB. Present position of immunization against poliomyelitis with live virus vaccines. British Medical Journal, 1959;i:663-80.

[125] Mahmias AJ, et al. Evidence for human infection with an HTLV III/LAVlike virus in Central Africa, 1959. Lancet, 1986;1:1279-80.

[126] Huminer D, et al. AIDS in the pre-AIDS era. Rev Infect Dis, 1987; 9:1102 8.

[127] Corbitt G, et al. HIV infection in Manchester, 1959. Lancet, 1990;ii:51.

[128] Cohen J. Debate on AIDS origin: Rolling Stone weighs in - Controversial article angers vaccine experts by claiming AIDS could have been spread by polio vaccines in Africa. Science, March 1992:1505.

[129] Hrdy DB. Cultural practices contributing to the transmission of human immunodeficiency virus in Africa. Rev Infect Dis, 1987; 9:1109-19.

[130] Sonnet J, et al. Early AIDS cases originating from Zaire and Burtundi (1962-1976). Scandinavian Journal of Infectious Disease, 1987;19:511-7.

[131] Gallo R. Virus Hunting. New York: HarperCollins, 1991.

[132] Tager A. Preliminary report on the treatment of recurrent herpes simplex with poliomyelitis vaccine(Sabin's). Dermatologica, 1974;149:253-5.

[133] Centers for Disease Control Task Force on Karposi's Sarcoma and Opportunistic Infections. Epidemiological aspects of the current outbreak of Kaposi's sarcoma and opportunistic infections. New England Journal of Medicine, 1982;306:252.

[134] Korn P. The New AIDS Mystery. Redbook, July 1994:82.

[135] Painter K. Usual routes of infection ruled out: 12-year-old's parents blame polio vaccine, but scientists discount that theory. USA Today, March 8 , 1994:A1.

[136] Extracted from a copy of the civil tort claim (U.S. District Court, New Jersey).

[137] Seven percent of the AIDS patients in Michigan have no identifiable cause of AIDS. As reported to the Thinktwice Global Vaccine Institute.

[138] Cowley G. Cannibals to cows: The path of a deadly disease. Newsweek, March 12, 2001:53.

[139] Center for Biologics Evaluation and Research. Bovine Spongiform Encephalopathy (BSE). FDA, January 23, 2001. [www.fda.gov/cber /bse/bseqa.htm] 
[140] Nature, 1996;381:743-4.

[141] Nature, 1996;383:685-690.

[142] Nature, 1997;389:498-501.

[143] PNAS, 1999;96:15137-242.

[144] Lancet, 1996;347:921-5.

[145] Center for Biologics Evaluation and Research. How did people get this new variant of CJD? FDA, January 23, 2001. www.fda.gov/cber/bse/bseqa.htm

[146] Mad Cow Homepage. Two million children inoculated with BSE vaccines. Daily Express, May 2, 2000. www.mad-cow.org/00/may00news.html

[147] Marwick C. FDA calls bovine-based vaccines currently safe. JAMA September 13, 2000. www.jama.ama-assn.org/issues/v284n10/ffull/jmn09133 .html

[148] Mercola J. U.K. recalls polio vaccine over 'Mad Cow' fears. October 29, 2000. www.mercola.com/2000/oct/29/polio_vaccine_recall.htm

[149] Center for Biologics Evaluation and Research. If vaccines are safe, why did the U.K. recall their polio vaccine? FDA, January 23, 2001. www.fda.gov/cber/bse/bseqa.htm

[150] Hawkes N. BSE fears over polio vaccinations. The Times, October 21, 2000. www.thetimes.co.uk/article $/ 0,23055,00 . \mathrm{html}$

[151] Figures taken from Department of Health Reports, U.K., October 2, 2000. www.doh.gov.uk/cjd

[152] Meikle J. Vaccine fiasco exposes loopholes. Guardian Newspapers Unlimited, October 21, 2000. www.guardianunlimited.co.uk/uk_news/story/ $0,3604,385958,00 . \mathrm{html}$

[153] FDA. Points to consider in the characterization of cell lines used for the production of biologics. The Center for Biologics Evaluation and Research, December 1993.

[154] Wilcox G. Farm Sanctuary. Proposed rule to ban substances in animal food [Docket No. 96-N-0135] (May 15, 1999). In a letter to the FDA.

[155] Marsh R. Dev Biol Stand, 1993; 80:111-8.

[156] Cutlip RC. Journal of Infectious Diseases 1994; 169:814-20.

[157] Rustigan R, et al. Infection of monkey kidney tissue cultures with virus-like agents. Proc Soc Exp Biol Med, 1955; 88:8-16.

[158] Morris JA, et al. Recovery of cytopathogenic agent from chimpanzees with coryza (22538). Proc Soc Exp Biol Med, 1956;92:544-9.

[159] Scheibner V. Vaccination: 100 Years of Orthodox Research Shows that Vaccines represent a Medical Assault on the Immune System. Blackheath, NSW, Australia: Scheibner Publications, 1993153.

[160] Parrot RH, et al. II. Serological studies over a 34-month period in children with bronchiolitis, pneumonia and minor respiratory diseases. Journal of the American Medical Association, 1961;176(8):653-57.

[161] Chanock RM, et al. Respiratory syncytial virus. Journal of the American Medical Association 1961;176(8):647-53.

[162] Hamparian V, et al. Recovery of new viruses (coryza) from cases of common cold in human adults. Proc Soc Exp Med Biol, 1961;108:444-53.

[163] CDC. Respiratory syncytial virus, June 21, 1999. www.cdc.gov/ncidod/ dvrd/nrevss/rsvfeat.htm

[164] Public Health Laboratory Service. Seasonal diseases: respiratory syncytial virus. March 16, 2000. www.phls.co.uk/seasonal/rsv/RSV13.htm

[165] The Triplet Connection. RSV—a serious subject. 2000. www.triplet connection.com/rsv_new.html

[166] Applied Genetics News. Eat your vaccine, dear. August 2000. www.find articles.com/cfdls/m0DED/121/65016226/p1/article.jhtml

[167] Martin J, et al. African green monkey origin of the atypical cytopathic 'stealth virus' isolated from a patient with chronic fatigue syndrome. Clinical and Diagnostic Virology, 1995;4:93-103.

[168] Fisher B. Microbiologist issues a challenge to science: did the first oral polio vaccine lots contaminated with monkey viruses create a monkeyhuman hybrid called HIV-1? The Vaccine Reaction, April 1996:3.

[169] Eighth Annual Houston Conference on AIDS in America, 1996.

[170] American Journal of Hygiene, 1958;68:31-44.

[171] Urnovitz HB, et al. Urine Antibody Tests: New Insights into the Dynamics of HIV-1 Infection. Clin Chem. 1999; 45:1602-13.

[172] World Health Organization. Problems with eradicating polio. Science News, November 25, 2000:348.

[173] Reuters Health. Polio outbreak in Dominican Republic and Haiti Caused by vaccine-derived virus. Reuters Medical News. December 4, 2000. www.id.medscape.com/reuters/prof/2000/12/12.05/20001204epid001.html
[174] Crainic R, et al. Polio virus with natural recombinant genomes isolated from vaccine associated paralytic poliomyelitis. Virology 1993;196:199208.

[175] Yoshida H, et al. Lancet, October 28, 2000.

[176] Associated Press. Monkey virus stirs debate: should animals be used to produce vaccines? CNN Interactive, January 29, 1997.

[177] In a presentation at a Vaccine Safety Forum Workshop: Institute of Medicine (November 1995).

\section{About the Author}

Neil Z. Miller is a medical research journalist and natural health advocate. He is the author of numerous articles and books on vaccines, including Vaccines: Are They Really Safe and Effective? (updated and revised 2004); Vaccines, Autism and Childhood Disorders (2003); Immunizations: The People Speak (1996); and Immunization Theory Versus Reality (1995). He is a frequent guest on radio and TV talk shows, including Donahue and Montel Williams, where he is often seen and heard debating doctors and other health officials. Mr. Miller has a degree in psychology, is the director of the Thinktwice Global Vaccine Institute (www.thinktwice.com), and is a member of Mensa, the international high-IQ society. He lives in Northern New Mexico with his family.

Mr. Miller began his crusade against mandatory vaccines when his son was born. Very little data could be found on this topic. His search for the truth led him to scientific journals. There he discovered numerous studies warning medical practitioners that vaccines are often unsafe and ineffective. His shock and anger at the suppression of this information culminated in his passionate advocacy of health freedom and informed parenting options.

Neil Miller is a health pioneer who presented documentation about vaccine safety and efficacy problems long before these concerns were made public. For example, several years ago he complained about toxic mercury being put into childhood vaccines and provided evidence linking vaccines and autism. During the past decade, cases of autism skyrocketed by more than 500 percent in countries that use the MMR vaccine. In some parts of the United States, one of every 150 children is autistic. Recently, Congress commanded the FDA to remove mercury from vaccines, and new studies by several world-renowned scientists confirmed an MMR-autism link.

Despite the many problems uncovered in Mr. Miller's research, he does not tell parents to reject the shots:

Every year, more than 12,000 people in the United States file vaccine-damage reports with the FDA documenting serious adverse reactions to mandated immunizations (children are mainly affected). The FDA estimates that this represents just 10 percent of the true rate. Yet, even these figures pale in comparison to the number of cases of new diseases scientifically linked to inoculations: MMR and autism, polio vaccines and cancer, the hepatitis $B$ vaccine and multiple sclerosis, the Hib vaccine and diabetes, to name just a few. For these reasons, among others, I am opposed to mandatory vaccines. I do not recommend for or against the shots. I want everyone to think through this enigmatic and controversial subject on their own. I believe that parents are capable of obtaining the facts and making knowledgeable choices regarding the care and welfare of their children.

Mr. Miller has publicly debated the pros and cons of mandatory vaccines with several pediatricians and other health practitioners, including the chief medical epidemiologist for the National Immunization Program at the Centers for Disease Control and Prevention (CDC). He conducts lectures throughout the United States and is available to discuss his research on vaccines. 